\title{
PENGARUH MODEL DISCOVERY LEARNING BERBANTUAN MULTIMEDIA TERHADAP KETERAMPILAN PROSES SAINS, BERPIKIR TINGKAT TINGGI DAN KETERAMPILAN BERTANYA PADA MATERI SISTEM PERNAPASAN DI SMA NEGERI 5 LANGSA
}

\author{
Rahmat Surya (ayrustamhar@gmail.com) \\ Universitas Sains Cut Nyak Dhien Langsa
}

\begin{abstract}
ABSTRAK
Penelitian ini bertujuan untuk mengetahui pengaruh model discovery learning berbantuan multi media terhadap: (1) Keterampilan proses sains pada materi sistem pernapasan di SMA Negeri 5 Langsa; (2) berpikir tingkat tinggi pada materi sistem pernapasan di SMA Negeri 5 Langsa; (3) keterampilan bertanya pada materi sistem pernapasan di SMA Negeri 5 Langsa. Penelitian ini merupakan kuasi eksperimen dengan sampel sebanyak tiga kelas dengan menggunakan teknik cluster random sampling. Kelas XI MIA 1 menggunakan model discovery learning; Kelas XI MIA 2 menggunakan model discovery learning berbantuan multimedia dan; kelas XI MIA 3 menggunakan model direct interaction. Instrumen penelitian menggunakan soal uraian untuk menguji keterampilan proses sains, berpikir tingkat tinggi dan lembar observasi untuk melihat keterampilan bertanya siswa. Teknik analisa data menggunakan uji ANACOVA yang dilanjutkan dengan uji Tukey's pada taraf signifikansi $\alpha=0,05$ dengan SPSS21,0. Hasil penelitian menunjukan bahwa terdapat pengaruh signifikan model discovery learning berbantuan multimedia terhadap keterampilan proses sains $(92,057 \pm 5,585)$, discovery learning (81,458 $\pm 11,647)$, dan direct interaction $(73,417 \pm 13,682)$ dengan nilai $F=24,080, \quad p=0,000$; Adanya pengaruh signifikan model discovery learning berbantuan multimedia terhadap berpikir tingkat tinggi $(87,499 \pm 10,03)$, discovery learning $(79,703 \pm 10,79)$, dan direct interaction $(73,897 \pm 13,38)$ dengan nilai $F=11,485, p=0,000$; (3) terdapat pengaruh yang signifikan keterampilan bertanya dengan model pembelajaran discovery learning berbantuan multimedia dimana siswa yang bertanya lebih banyak dibandingkan dengan model discovery learning dan direct interaction. Dapat disimpulkan bahwa siswa yang dibelajarkan dengan model discovery learning berbantuan multimedia nilai keterampilan proses sains, berpikir tingkat tinggi dan keterampilan bertanya lebih tinggi dibandingkan dengan pembelajaran model discovery learning dan direct interaction.
\end{abstract}

Kata Kunci : Berbantuan Multimedia, Keterampilan Bertanya, Keterampilan Proses Sains, Berpikir Tingkat Tinggi, Model Discovery Learning

\begin{abstract}
This research is aimed to study effect of discovery learning model assisted multimedia on: (1) Science Process Skillof students SMA Negeri 5 Langsa at Topic Respiratory system; (2) high order thinking of students SMA Negeri 5 Langsa at Topic Respiratory system; (3) the ability to Asking of students SMA Negeri 5 Langsa at Topic Respiratory system. This quasi experiment with a sample of three classes using cluster random sampling technique. Class XI MIA 1 used a model of discovery learning; Class XI MIA 2 used discovery learning assisted multimedia; class XI MIA 3 used a direct instruction model (control). The research instrument is a matter of description to test the science process skills and high order thinking and observation sheet format for the ability to asking. The technique of data analiysis was ANACOVA followed by Tukey's test at the level of significance $\alpha=0,05$ by using SPSS 21,0. The research result showed: (1) There was significant effect of discovery learning model assisted multimedia $(92,057 \pm 5,585)$, discovery learning model $(81,458 \pm 11,647)$, direct interaction $(73,417 \pm 13,682)$ to Science Process Skill with $F=24,080, p=0,000$; (2) There was significant effect of discover y learning model assisted multimedia $(87,499 \pm 10,03)$, discovery learning model $(79,703 \pm 10,79)$, direct interaction $(73,897 \pm 13,38)$ to high order thinking with $F=11,485$, $p=0,000$; (3) There was significant effect asking the learning model, the model of discovery learning model assisted multimedia more participants were asked compared with discovery learning and Direct interaction model.
\end{abstract}

Keywords: Ability to asking, Assisted Multimedia, Discovery Learning Model, High Order Thinking, Science Process Skill 
Rahmat Surya, Pengaruh Model Discovery Learning Berbantuan Multimedia Terhadap Keterampilan Proses Sains Berpikir Tingkat Tinggi dan Keterampilan Bertanya

\section{JURNAL BIOLOKUS Vol.3 (1)}

\section{PENDAHULUAN}

Hakikat pembelajaran Sains (Biologi) yaitu mengacu pada tiga aspek: produk, proses, dan sikap ilmiah. Menurut Carin dan Evans (dalam Sudarisman, 2010) pembelajaran sains setidaknya meliputi empat hal, yaitu: produk (content), proses, sikap dan teknologi. Berdasarkan tujuan tersebut, guru semestinya kreatif memilih pembelajaran yang dapat memupuk kemampuan berpikir dan sikap peserta didik.

Proses pembelajaran yang ada selama ini belum optimal karena peserta didik masih belum aktif dalam mengikuti pembelajaran. Peserta didik hanya duduk diam dan mendengarkan materi dari guru. pembelajaran yang sering dilakukan oleh guru adalah pembelajaran ekspositori (exspository learning) yang merupakan proses pembelajaran berpusat pada guru (teacher centered). Pembelajaran seperti ini akan mengakibatkan keterampilan berpikir kritis peserta didik kurang optimal dan hal ini tidak sesuai dengan standar kompetensi lulusan menurut Peraturan Menteri No 23 Tahun 2006.

Di samping itu guru jarang menggunakan multimedia sebagai media pembelajaran di kelas. Kenyataan di sekolah terdapat beberapa alat multimedia yang bisa digunakan dalam pembelajaran. Guru tidak menggunakan multimedia sebagai media pembelajaran karena kemampuan guru menggunakan alat multimedia terbatas dan masih kurangnya pelatihan guru dalam alat alat multimedia. Seharusnya sebagaimana pendapat Yeoman (2014) menyatakan guru harus jeli memanfaatkan teknologi informasi sebagai media pembelajaran dalam menggunkan model pembelajaran karena mengimplementasikan multimedia berpengaruh terhadap hasil belajar peserta didik.

Hasil riset yang dilakukan oleh Proramme for International Student Assessment (PISA) pada tahun 2018. Survey ini mengikutkan siswa yang berusia 15 tahun dari 79 negara, yang tergolong dalam negara maju dan negara berkembang. PISA menyatakan bahwa berdasarkan kemampuan membaca Indonesia menduduki peringkat 72 dengan nilai 371 , kemampuan matematika pada peringkat 72 dengan nilai 379 dan kemampuan sain pada peringkat 74 dengan nilai 396 (OECD, 2018). Survey Trend International Mathematics Science (TIMSS) tahun 2015 melaporkan tentang nilai rata- rata sains pada domain kognitif yang merupakan aspek penting dalam kemampuan pemecahan masalah. Indonesia berada pada tingkat 45 dari 50 negara di dunia. Indonesia memperoleh skor knowing adalah 425, applying adalah 426 dan reasoning 438 yang dibawah skor rata-rata TIMSS, yaitu 500. Sedangkan data dari Dinas Pendidikan Provinsi Aceh diperoleh nilai Ujian Nasional tahun 2014-2015 untuk pelajaran IPA menduduki peringkat paling bawah dibandingkan mata pelajaran lain dengan rincian Bahasa Indonesia 65,31, Bahasa Inggris 65,21, Matematika 65,82 sedangkan IPA 62,68.

Hal ini dapat terjadi karena kecenderungan pembelajaran IPA/ Sains di Indonesia yang dikemukakan oleh Depdiknas (2007), bahwa: (1) Pembelajaran hanya berorientasi pada tes/ujian; (2) Pengalaman belajar yang diperoleh dikelas tidak utuh dan tidak berorientasi pada tercapainya standart kompetensi dan kompetensi dasar; (3) pembelajaran lebih bersifat teacher centered; (4) siswa hanya mempelajari IPA pada domain kognitif yang terendah dan tidak dibiasakan untuk mengembangkan potensi berpikirnya; (5) cara berpikir yang dikembangkan dalam kegiatan belajar belum menyentuh domain affektif dan psikomotor; (6) alasan yang sering dikemukakakan oleh para guru adalah keterbatasan waktu, sarana, lingkungan belajar, dan jumlah siswa per kelas terlalu banyak; dan (7) evaluasi yang dilakukan hanya berorientasi pada produk belajar yang berkaitan dengan domain kognitif dan tidak menilai proses.

Pembelajaran biologi di SMA mempunyai kecenderungan dalam pembelajarannya banyak pengembangan konsep dalam kehidupan seharihari di samping juga pengembangan kegiatan ilmiahnya. Didalam konsep biologi tetsebut dalam pembelajarannya masih dominan aktivitas pada guru, sehingga timbul kesan biologi diajarkan dalam definisi-definisi atau pengertian-pengertian saja.

Discovery learning adalah model belajar yang didefinisikan sebagai proses pembelajaran yang terjadi bila pembelajar tidak disajikan dengan pelajaran dala m bentuk finalnya, tetapi diharapkan mengorganisasi sendiri. Konsep dasar pembelajaran penemuan (discovery learning) adalah bahwa guru harus memfasilitasi instruksi yang memungkinkan peserta didik untuk menemukan hasil yang telah ditentukan sesuai dengan tingkat belajar yang diperlukan oleh standar kurikulum (Champina et al 2009). 
Rahmat Surya, Pengaruh Model Discovery Learning Berbantuan Multimedia Terhadap Keterampilan Proses Sains Berpikir Tingkat Tinggi dan Keterampilan Bertanya

JURNAL BIOLOKUS Vol.3 (1)

Dalam kurikulum 2013 selain menekankan menggunakan model pembelajaran penemuan (discovery learning) melalui mengamati, menanya, mencoba, menalar dan menyaji juga menggiring peserta didik untuk menemukan konsep yang sedang dipelajari melalui deduksi, diajak untuk mencari tahu bukan diberi tahu. Di samping lebih menekankan metode eksperimen, namun tidak sekedar pembelajaran praktik melainkan lebih menekankan pada penemuan konsep oleh peserta didik melalui berbagai aktivitas kognitif selama pengamatan terhadap suatu fakta berlangsung. Hal ini sangat erat kaitannya dengan kreativitas peserta didik. Proses pembelajaran yang mendukung kreativitas peserta didik menurut Dyerset al (2011) bahwa dua pertiga dari kemampuan kreativitas seseorang diperoleh dari pendidikan sedang sisanya berasal dari genetik. Kemampuan kreativitas seseorang diperoleh melalui observing (mengamati), questioning (menanya), associating (menalar), experimenting (mencoba) dan networking (membentuk jejaring).

Penelitian yang dilakukan oleh Swaak et al (2004) menyatakan bahwa jenis pembelajaran yang meminta tanggungjawab yang besar pada peserta didik seperti ekspositori. Sejalan dengan hasil penelitian. Sejalan dengan hasil penelitian tersebut salah satu model yang dapat meningkatkan keberhasilan peserta didik lebih diarahkan pada proses pembelajaran yang mengaktifkan siswa untuk memperoleh berbagai macam kemampuan yang dapat dianggap relevan untuk meningkatkan keterampilan proses sains, kemampuan berpikir tingkat tinggi dan keterampilan bertanya siswa. Berdasarkan latar belakang tersbut penulis tertarik untuk mengetahui pengaruh model discovery learning berbantuan multimedia terhadap keterampilan proses sains, berpikir tingkat tinggi dan keterampilan bertanya pada materi sistem pernapasan.

\section{METODE}

Jenis penelitian ini adalah penelitian quasi ekperimen. Rancangan penelitian yang digunakan adalah rancangan ekperimen dengan desain non-faktorial yang membandingkan model pembelajaran discovery learning ( $D L$ ) berbantuan multimedia dengan model pembelajaran Diriect Interaction (DI). Dalam penelitian ini variabel bebas. Desain yang digunakan adalah "pra-tes dan pasca-tes dengan kelompok- kelompok acak" atau pretest control group design. Dalam desain ini kelompok ekperimen diajar dengan model pembelajaran Discovery learning berbantuan multimedia sedangkan kelompok kelas kontrol diajar dengan menggunakan model pembelajaran direct interaction. Desain penelitian ini dapat dilihat pada Tabel 1.

\begin{tabular}{cccc} 
Tabel 1 & Pretest-Postest & Control Grop & \\
\hline Kelas & Pretes & Perlakuan & Postes \\
\hline $\mathrm{A}$ & $\mathrm{T}_{1} \mathrm{~T}_{2} \mathrm{~T}_{3}$ & $\mathrm{X}_{1}$ & $\mathrm{~T}_{1} \mathrm{~T}_{2} \mathrm{~T}_{3}$ \\
$\mathrm{~B}$ & $\mathrm{~T}_{1} \mathrm{~T}_{2} \mathrm{~T}_{3}$ & $\mathrm{X}_{2}$ & $\mathrm{~T}_{1} \mathrm{~T}_{2} \mathrm{~T}_{3}$ \\
$\mathrm{C}$ & $\mathrm{T}_{1} \mathrm{~T}_{2} \mathrm{~T}_{3}$ & $\mathrm{X}_{3}$ & $\mathrm{~T}_{1} \mathrm{~T}_{2} \mathrm{~T}_{3}$ \\
\hline
\end{tabular}

Keterangan:

$\mathrm{X} 1$ : Perlakuan dengan model pembelajaran Discovery learning

$\mathrm{X}_{2}$ : Perlakuan dengan model pembelajaran Discovery learning berbantuan multimedia

X3 : Perlakukan dengan model pembelajaran Direct Interaction

$\mathrm{T} 1$ : Keterampilan proses sains

T2 : Kemampuan berpikir tingkat tinggi

T3 : Keterampilan bertanya

\section{Instrumen Tes Keterampilan Proses Sains}

Instrumen ketrampilan proses sains menggunakan instrumen penelitian yang terdiri dari 9 item yang meliputi mengamati, mengklasifikasi, menginterpretasi, memprediksi, merencanakan percobaan, menerapkan konsep, mengajukan pertanyaan dan mengkomunikasikan hasil. Tes ketrampilan proses sains dibuat dalam bentuk soal esai yang dikembangkan oleh penulis. Sebelum digunakan dalam penelitian, dilakukan validitas terhadap setiap soal keterampilan proses sains, kemudian soal-soal yang diujikancobakan kepada sampel sebanyak 20 soal esai. Kisi- kisi soal keterampilan sains dapat dilihat pada Tabel 2 . 
Rahmat Surya, Pengaruh Model Discovery Learning Berbantuan Multimedia Terhadap Keterampilan Proses Sains Berpikir Tingkat Tinggi dan Keterampilan Bertanya

JURNAL BIOLOKUS Vol.3 (1)

Tabel 2. Kisi-kisi Soal Keterampilan Proses Sains

\begin{tabular}{lllcc}
\hline No & Jenis Keterampilan & \multicolumn{1}{c}{ Indikator } & $\begin{array}{c}\text { Nomor } \\
\text { Soal }\end{array}$ & $\begin{array}{c}\text { Skor } \\
\text { Maksimal }\end{array}$ \\
\hline 1 & Observasi & $\bullet$ Menggunakan sebanyak mungkin indera & 1,7 & 4 \\
\hline 2 & Interpretasi & $\bullet$ Menyimpulkan hasil pengamatan & 2,8 & 4 \\
\hline 3 & Berhipotesis & $\begin{array}{l}\text { - Menyadari bahwa suatu penjelasan perlu diuji } \\
\text { kebenarannya dengan memperoleh bukti }\end{array}$ & 3,9 & 4 \\
\hline 4 & $\begin{array}{l}\text { Merencanakan } \\
\text { percobaan }\end{array}$ & $\begin{array}{l}\bullet \text { Menentukan alat/bahan yang digunakan } \\
\bullet \text { Menentukan prosedur suatu percobaan }\end{array}$ & 4,10 & 4 \\
\hline 5 & $\begin{array}{l}\text { Menerapkan } \\
\text { Konsep }\end{array}$ & $\begin{array}{l}\text { - Menggunakan konsep pada } \\
\text { sedang terjadi }\end{array}$ & 5,11 & 4 \\
\hline 6 & Berkomunikasi & $\begin{array}{l}\bullet \text { Menyampaikan laporan secara sistematis dan } \\
\text { jelas }\end{array}$ & 6,12 & 4 \\
\hline & \multicolumn{2}{|c|}{ Jumlah } & 12 & 24 \\
\hline
\end{tabular}

\section{Instrumen Tes Kemampuan Berpikir Tingkat} Tinggi Siswa

Tes kemampuan berpikir tingkat tinggi dibuat dalam bentuk tes eassy. Instrumen ini digunakan untuk mengukur perubahan kemampuan siswa sebagai hasil kemampuan berpikir tingkat tinggi Biologi setelah mengikuti kegiatan pembelajaran dari pokok bahasan yang diajarkan. Kisi-kisi tes kemampuan berpikir tingkat tinggi dapat dilihat pada Tabel 3.

Tabel 3. Kisi-kisi Tes Kemampuan Berpikir Tingkat Tinggi.

\begin{tabular}{|c|c|c|c|c|c|}
\hline \multirow[t]{2}{*}{ No } & \multirow[t]{2}{*}{ Indikator } & \multicolumn{3}{|c|}{$\begin{array}{c}\text { Aspek yang } \\
\text { dinilai }\end{array}$} & \multirow{2}{*}{$\begin{array}{l}\text { Jum } \\
\text { lah } \\
\text { Soal }\end{array}$} \\
\hline & & C4 & $\mathrm{C5}$ & C6 & \\
\hline 1. & $\begin{array}{l}\text { Struktur sistem } \\
\text { pernapasan pada } \\
\text { manusia }\end{array}$ & 8 & 5 & & 2 \\
\hline 2. & $\begin{array}{l}\text { Proses sistem } \\
\text { pernapasan } \\
\text { manusia } \\
\end{array}$ & 1,2 & & & 2 \\
\hline \multirow[t]{2}{*}{3.} & $\begin{array}{l}\text { Penyakit dan } \\
\text { kelainan pada } \\
\text { sistem pernapasan }\end{array}$ & 6 & 7 & 3,4 & 4 \\
\hline & Jumlah & 4 & 2 & 2 & 8 \\
\hline
\end{tabular}

\section{Keterangan}

$\mathrm{C} 4=$ Analisis

$\mathrm{C} 5=$ Evaluasi

C6 $=$ Kreasi

\section{Pengamatan Keterampilan Bertanya}

Selain melihat Keterampilan tingkat tinggi pada peserta didik peneliti juga akan melihat keterampilan bertanya pada materi sistem pernapasan di SMA Negeri 5 Langsa. Dalam penelitian ini peneliti akan menggunakan dimensi proses kognitif Taksonomi Blomm.
Tabel 4. Pengamatan Keterampilan Bertanya

\begin{tabular}{|c|c|c|c|c|c|c|c|c|}
\hline \multirow{2}{*}{ Kel } & \multirow{2}{*}{$\begin{array}{l}\text { Nama } \\
\text { Siswa }\end{array}$} & \multicolumn{6}{|c|}{ Aspek Kognitif } & \multirow{2}{*}{ Jumlah } \\
\hline & & C1 & $\mathrm{C} 2$ & C3 & C4 & C5 & C6 & \\
\hline \multicolumn{9}{|l|}{1} \\
\hline \multicolumn{9}{|l|}{2} \\
\hline \multicolumn{9}{|l|}{3} \\
\hline 4 & & & & & & & & \\
\hline 5 & & & & & & & & \\
\hline
\end{tabular}

Analisis data penelitian dilakukan terhadap dua hal pokok yaitu uji persyaratan dan pengujian hipotesis, dengan langkah-langkah sebagai berikut:

a. Mengkonversikan skor perolehan siswa ke dalam nilai skala 1-100, dengan rumus

$$
\text { Nilai }=\frac{\text { Jumlah Skor yang diperoleh siswa }}{\text { Skor Maksimum }} \times 100 \%
$$

(Arikunto, 2003)

b. Menghitung rata-rata untuk masing-masing variabel dengan rumus (Sudjana, 1992): $\overline{\mathrm{X}}=\Sigma$ xin

c. Menentukan simpangan baku masing-masing variabel dengan rumus (Sudjana, 1992):

$\mathrm{SD}=\sqrt{\mathrm{n}} \Sigma \mathrm{Xi} 2-(\Sigma \mathrm{Xi}) 2 \mathrm{n}(\mathrm{n}-1)$

d. Pengujian Normalitas Data

Uji normalitas data dilakukan untuk memeriksa apakah data sampel yang diperoleh dari populasi memiliki sebaran berdistribusi normal atau tidak. Uji normalitas data dianalisis dengan uji Lilliefors (Sudjana, 1992), atau dengan pendekatan Kolmogorov-Smirnov menggunakan program SPSS 21.0 for windows.

e. Pengujian Homogenitas

Uji homogenitas bertujuan untuk menguji apakah kelompok-kelompok yang dijadikan 
Rahmat Surya, Pengaruh Model Discovery Learning Berbantuan Multimedia Terhadap Keterampilan Proses Sains Berpikir Tingkat Tinggi dan Keterampilan Bertanya

JURNAL BIOLOKUS Vol.3 (1)

sampel penelitian berasal dari populasi yang sama, artinya penyebarannya dalam populasi bersifat homogeny. Untuk mengetahuinya digunakan uji Fisher (Sudjana, 1992), atau menggunakan pendekatan Levene's Test dengan bantuan program SPSS 21 for windows.

f. Pengujian Hipotesis

Setelah persyaratan terpenuhi (normalitas dan homogenitas) selanjutnya dilakukan pengujian hipotesis. Untuk pengujian hipotesis, perlu dirumuskan hipotesis statistik berikut :

$$
\begin{array}{r}
\text { 1. } \mathrm{H} 0: \mu \mathrm{A} 1=\mu \mathrm{A} 2=\mu \mathrm{A} 3 \\
\text { Ha }: \mu \mathrm{A} 1 \neq \mu \mathrm{A} 2 \neq \mu \mathrm{A} 3 \\
\text { 2. } \mathrm{H} 0: \mu \mathrm{B} 1=\mu \mathrm{B} 2=\mu \mathrm{B} 3 \\
\text { Ha }: \mu \mathrm{B} 1 \neq \mu \mathrm{B} 2 \neq \mu \mathrm{B} 3 \\
\text { 3. } \mathrm{H} 0: \mu \mathrm{C} 1=\mu \mathrm{C} 2=\mu \mathrm{C} 3 \\
\text { Ha }: \mu \mathrm{C} 1 \neq \mu \mathrm{C} 2 \neq \mu \mathrm{C} 3
\end{array}
$$

Tabel 5. Nilai Pretes Keterampilan Proses Sains Siswa

\begin{tabular}{clcccccccc}
\hline & \multicolumn{1}{c}{ Model } & N & Range & Min & Max & Mean & $\begin{array}{c}\text { Std. Error } \\
\text { Mean }\end{array}$ & $\begin{array}{c}\text { Std. } \\
\text { Deviation }\end{array}$ & Variance \\
\hline \multirow{2}{*}{$\begin{array}{c}\text { Nilai } \\
\text { Pretest }\end{array}$} & $\begin{array}{l}\text { Discovery } \\
\text { Discovery+ }\end{array}$ & 31 & 27,08 & 14,58 & 41,67 & 21,5058 & 1,44388 & 8,03916 & 64,628 \\
& multimedia & 32 & 25,00 & 8,33 & 33,30 & 16,5406 & 1,20285 & 6,80436 & 46,299 \\
& Direct Interaction & 34 & 35,42 & 8,33 & 43,75 & 22,6097 & 1,44567 & 8,42962 & 71,058 \\
\hline
\end{tabular}

Hasil pretes menunjukan bahwa keterampilan awal siswa kelas direct interaction $(22,60 \pm 8,429)$ lebih tinggi dibandingkan dengan kelas discovery $(21,50 \pm 8,039)$ dan kelas discovery berbantuan multimedia $(16,540 \pm 6,804)$.
Keterangan :

$\mu \mathrm{A}$ : Keterampilan Proses Sains Kemampuan Berpikir Tingkat Tinggi

$\mu \mathrm{B}$ : Kemampuan Berpikir Tingkat Tinggi

$\mu \mathrm{C}$ : Keterampilan Bertanya

1 : Kelas Discovery Learning

2 : Kelas Discovery learning berbantuan multimedia

3 : Kelas Direct Interaction (Pembelajaran Langsung)

\section{HASIL DAN PEMBAHASAN}

\section{Deskripsi Data Keterampilan Proses Sains}

Sebelum diterapkan perlakuan pada tiap kelas, terlebih dahulu dilakukan tes kemampuan awal (pretes) keterampilan proses sains mengenai sistem pernapasan pada manusia. Data kemampuan awal (pretes) disajikan dalam Tabel 5.:

Tabel 6. Nilai Postes Keterampilan Proses Sains Siswa

\begin{tabular}{llcccccccc}
\hline & \multicolumn{1}{c}{ Model } & N & Range & Min & Max & Mean & $\begin{array}{c}\text { Std. Error } \\
\text { Mean }\end{array}$ & $\begin{array}{c}\text { Std. } \\
\text { Deviation }\end{array}$ & Variance \\
\hline \multirow{2}{*}{$\begin{array}{l}\text { Nilai } \\
\text { Postest }\end{array}$} & Discovery & 31 & 37,50 & 62,50 & 100 & 81,4581 & 2,09198 & 11,64765 & 135,668 \\
& Discovery+ & 32 & 20,83 & 79,17 & 100 & 92,0578 &, 98739 & 5,58550 & 31,198 \\
& Direct Interaction & 34 & 64,60 & 33,30 & 97,90 & 73,4176 & 2,34660 & 13,68289 & 187,221 \\
\hline
\end{tabular}

Hasil postes menunjukan bahwa $(81,458 \pm 11,647)$ dan kelas direct interaction keterampilan proses sains kelas discovery $(73,417 \pm 13,682)$.

berbantuan multimedia $(92,057 \pm 5,585)$ lebih $\quad$ 2. Deskripsi Data Berpikir Tingkat Tinggi tinggi dibandingkan dengan kelas discovery Data kemampuan awal (pretes) disajikan dalam Tabel 7:

Tabel 7. Nilai Pretes Berpikir Tingkat Tinggi Siswa

\begin{tabular}{llllllllll}
\hline & Model & N & Range & Min & Max & Mean & $\begin{array}{c}\text { Std. Error } \\
\text { Mean }\end{array}$ & $\begin{array}{c}\text { Std. } \\
\text { Deviation }\end{array}$ & Variance \\
\hline \multirow{2}{*}{$\begin{array}{l}\text { Nilai } \\
\text { Pretest }\end{array}$} & $\begin{array}{l}\text { Discovery } \\
\text { Discovery }+\end{array}$ & 31 & 29,17 & 25,00 & 54,17 & 33,4671 & 1,39969 & 7,79316 & 60,733 \\
& $\begin{array}{l}\text { multimedia } \\
\text { Direct } \\
\text { Interaction }\end{array}$ & 32 & 25,00 & 12,50 & 37,50 & 25,0013 & 1,28256 & 7,25527 & 52,639 \\
& 34 & 37,50 & 8,33 & 45,83 & 20,8338 & 1,35122 & 7,87892 & 62,077 \\
\hline
\end{tabular}


Rahmat Surya, Pengaruh Model Discovery Learning Berbantuan Multimedia Terhadap Keterampilan Proses Sains Berpikir Tingkat Tinggi dan Keterampilan Bertanya

\section{JURNAL BIOLOKUS Vol.3 (1)}

Hasil pretes menunjukan bahwa keterampilan berpikir tingkat tinggi awal siswa kelas discovery $(33,46 \pm 7,793)$ lebih tinggi dibandingkan dengan kelas discovery berbantuan multimedia $(25,00 \pm 7,25)$ dan kelas Direct
Interaction $(20,83 \pm 7,878)$. Selanjutnya dilakukan perlakuan dan diperoleh data berpikir tingkat tinggi siswa (postes). Data berpikir tingkat tinggi siswa (postes) disajikan pada Tabel 8:

Tabel 8. Nilai Postes Berpikir Tingkat Tinggi Siswa.

\begin{tabular}{llrrrrrrrr}
\hline \multicolumn{1}{c}{ Model } & N & Range & Min & Max & Mean & $\begin{array}{c}\text { Std. Error } \\
\text { Mean }\end{array}$ & $\begin{array}{c}\text { Std. } \\
\text { Deviation }\end{array}$ & Variance \\
\hline \multirow{2}{*}{$\begin{array}{l}\text { Nilai } \\
\text { Postest }\end{array}$} & Discovery & 31 & 33,33 & 62,50 & 95,83 & 79,7032 & 1,93943 & 10,79826 & 116,603 \\
& $\begin{array}{l}\text { multimedia } \\
\text { Direct Interaction }\end{array}$ & 32 & 33,33 & 66,67 & 100 & 87,4994 & 1,77469 & 10,03917 & 100,785 \\
& 66,66 & 29,17 & 95,83 & 73,8971 & 2,29571 & 13,38620 & 179,190 \\
\hline
\end{tabular}

Hasil postes menunjukan bahwa keterampilan berpikir tingkat tinggi kelas discovery berbantuan multimedia $(87,49 \pm 10,03)$ lebih tinggi dibandingkan dengan kelas discovery $(79,70 \pm$ $10,79)$ dan kelas direct interaction $(73,89 \pm 13,38)$.

\section{PENGAJUAN PERSYARATAN \\ a. Uji Normalitas}

Uji normalitas setiap kelas eksperimen disajikan pada masing-masing tabel di bawah ini.

Tabel 9. Uji Normalitas Kelas Discovery

\begin{tabular}{lccc}
\hline \multicolumn{1}{c}{ Perlakuan } & $\begin{array}{c}\text { Uji } \\
\text { Kolmogrov- } \\
\text { Sminornov }\end{array}$ & $\begin{array}{c}\text { Probalitas } \\
(p)\end{array}$ & Keterangan \\
\hline $\begin{array}{l}\text { Keterampilan } \\
\text { Proses Sains }\end{array}$ & 0,631 & 0,820 & Normal \\
\hline $\begin{array}{l}\text { Keterampilan } \\
\text { Berpikir } \\
\text { Tingkat Tinggi }\end{array}$ & 0,848 & 0,468 & Normal \\
\hline
\end{tabular}

Berdasarkan Tabel 9. diperoleh nilai sig. $0,820>0,05$ untuk normalitas nilai keterampilan proses sains siswa pada kelas discovery, dengan demikian disimpulkan bahwa data berdistribusi normal. Uji normalitas berpikir tingkat tinggi siswa dengan nilai sig 0,468>0,05, yang artinya data berdistribusi normal.

Tabel 10. Uji Normalitas Kelas Discovery Berbantuan Multimedia.

\begin{tabular}{lccc}
\hline \multicolumn{1}{c}{ Perlakuan } & $\begin{array}{c}\text { Uji } \\
\text { Kolmogrov- } \\
\text { Sminornov }\end{array}$ & $\begin{array}{c}\text { Probalitas } \\
(p)\end{array}$ & Keterangan \\
\hline $\begin{array}{l}\text { Keterampilan } \\
\text { Proses Sains }\end{array}$ & 0,551 & 0,922 & Normal \\
\hline $\begin{array}{l}\text { Keterampilan } \\
\text { Berpikir } \\
\text { Tingkat Tinggi }\end{array}$ & 1,148 & 0,143 & Normal \\
\hline
\end{tabular}

Berdasarkan Tabel 10. diperoleh nilai sig. 0,922>0,05 untuk normalitas nilai keterampilan proses sains siswa pada kelas discovery berbantuan multimedia, dengan demikian disimpulkan bahwa data berdistribusi normal. Uji normalitas berpikir tingkat tinggi siswa dengan nilai sig 0,143>0,05, yang artinya data berdistribusi normal.

Tabel 11. Uji Normalitas Kelas Direct Interaction

\begin{tabular}{lccc}
\hline Perlakuan & $\begin{array}{c}\text { Uji } \\
\text { Kolmogrov- } \\
\text { Sminornov }\end{array}$ & $\begin{array}{c}\text { Probalita } \\
\mathrm{s}(p)\end{array}$ & $\begin{array}{c}\text { Kete } \\
\text { rangan }\end{array}$ \\
\hline $\begin{array}{l}\text { Keterampilan } \\
\text { Proses Sains }\end{array}$ & 1,116 & 0,166 & Normal \\
\hline $\begin{array}{l}\text { Keterampilan } \\
\text { Berpikir Tingkat } \\
\text { Tinggi }\end{array}$ & 0,871 & 0,433 & Normal \\
\hline
\end{tabular}

Berdasarkan Tabel 11. diperoleh nilai sig. 0,166>0,05 untuk normalitas nilai keterampilan proses sains siswa pada kelas direct interaction, dengan demikian disimpulkan bahwa data berdistribusi normal. Uji normalitas berpikir tingkat tinggi siswa dengan nilai sig $0,433>0,05$, yang artinya data berdistribusi normal.

\section{b. Uji Homogenitas}

Uji Homogenitas dimaksudkan untuk mengetahui perbedaan varians data masing-masing kelas eksperimen. Homogenitas data diuji dengan pendekatan Levene's test. Data dinyatakan homogen apabila nilai $\mathrm{P}>0,05$. Uji homogenitas dari masing-masing variable disajikan dalam tabel di bawah ini:

Tabel 12. Uji Homogenitas Keterampilan Proses Sains dan Keterampilan Berpikir Tingkat Tinggi

\begin{tabular}{lccc}
\hline \multicolumn{1}{c}{ Perlakuan } & $\begin{array}{c}\text { Uji } \\
\text { Levene's }\end{array}$ & $\begin{array}{c}\text { Probalitas } \\
(\mathrm{p})\end{array}$ & Keterangan \\
\hline $\begin{array}{l}\text { Keterampilan } \\
\text { Proses Sains }\end{array}$ & 1,912 & 0,153 & Homogen \\
\hline $\begin{array}{l}\text { Keterampilan } \\
\text { Berpikir Tingkat } \\
\text { Tinggi }\end{array}$ & 1,515 & 0,225 & Homogen \\
\hline
\end{tabular}

Berdasarkan Tabel 12. diperoleh nilai sig. $0,153>0,05$ untuk rata-rata nilai keterampilan proses sains siswa, 0,225>0,05 untuk berpikir 
Rahmat Surya, Pengaruh Model Discovery Learning Berbantuan Multimedia Terhadap Keterampilan Proses Sains Berpikir Tingkat Tinggi dan Keterampilan Bertanya

JURNAL BIOLOKUS Vol.3 (1)

tingkat tinggi. Dengan demikian, dapat disimpulkan bahwa varians keterampilan proses sains siswa dan keterampilan berpikir tingkat tinggi adalah homogen.

\section{Pengujian Hipotesis}

a. Pengaruh Model Discovery Learning Berbantuan Multimedia Terhadap keterampilan Proses Sains

Hasil analisis kovariat (Anacova) dengan bantuan SPSS 21.0 menunjukan bahwa model pembelajaran secara signifikan berpengaruh terhadap keterampilan proses sains siswa $(\mathrm{F}=24,080 ; \mathrm{P}=0,000)$. Selanjutnya uji Tukey menunjukan bahwa keterampilan proses sains siswa yang dibelajarkan dengan model discovery berbantuan multimedia $(92,057 \pm 5,585)$ secara signifikan lebih tinggi dibandingkan hasil keterampilan proses sains siswa yang dibelajarkan dengan model discovery $(81,458 \pm 11,647)$ dan direct interaction $(73,417 \pm 13,682$ ) (gambar 1 ). nilai signifikansi pengaruh model pembelajaran terhadap keterampilan proses sains siswa 0,000<0,05 maka Ho ditolak dan $\mathrm{Ha}$ diterima, maka dapat disimpulkan bahwa pada tingkat kepercayaan 95\% pengaruh model discovery, Discovery berbantuan multimedia dan direct interaction memberikan efek yang signifikan terhadap keterampilan proses sains siswa.

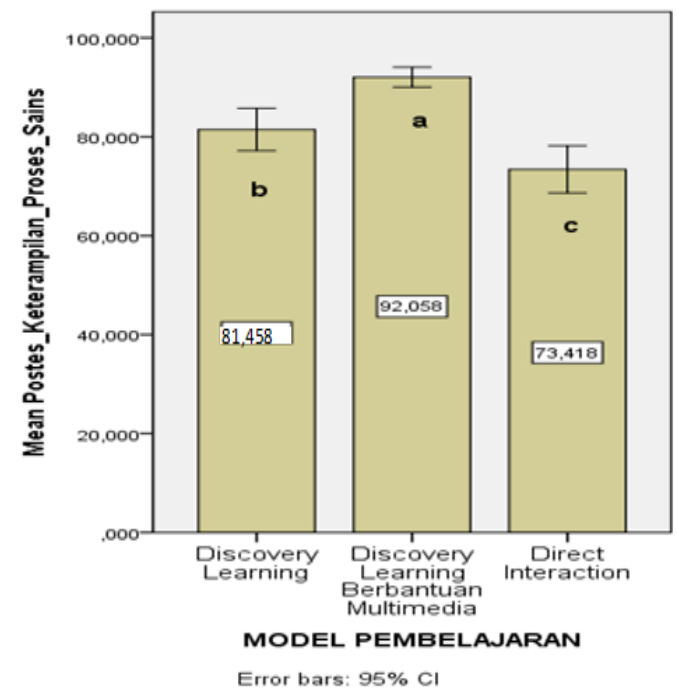

Gambar 1. Pengaruh model discovery learning, discovery learning berbantuan multimedia dan direct interaction terhadap keterampilan proses sains $(\mathrm{F}=24,080 ; \mathrm{P}=\mathbf{0 , 0 0 0}$ ). Huruf yang berbeda di atas diagram berarti berbeda signifikan (Uji Tukey).

b. Pengaruh Model Discovery Learning Berbantuan Multimedia Terhadap Keterampilan Berpikir Tingkat Tinggi

Hasil analisis kovariat (Anacova) dengan bantuan SPSS 21.0 menunjukan bahwa model pembelajaran secara signifikan berpengaruh terhadap keterampilan berpikir tingkat tinggi siswa $(F=11,485 ; P=0,000)$ (Lampiran 17). Selanjutnya uji Tukey menunjukan bahwa keterampilan berpikir tingkat tinggi siswa yang dibelajarkan dengan model discovery berbantuan multimedia $(87,499 \pm 10,03)$ secara signifikan lebih tinggi dibandingkan keterampilan berpikir tinggkat tinggi yang dibelajarkan dengan model discovery $(79,703 \pm 10,79)$ dan direct interaction $(73,897 \pm 13,38)$ (gambar 2). Nilai signifikansi pengaruh model pembelajaran terhadap keterampilan berpikir tingkat tinggi siswa 0,00<0,05 maka Ho ditolak dan Ha diterima, maka dapat disimpulkan bahwa pada tingkat kepercayaan 95\% pengaruh model discovery, Discovery berbantuan multimedia dan direct interaction memberikan efek yang signifikan terhadap keterampilan berpikir tingkat tinggi siswa.

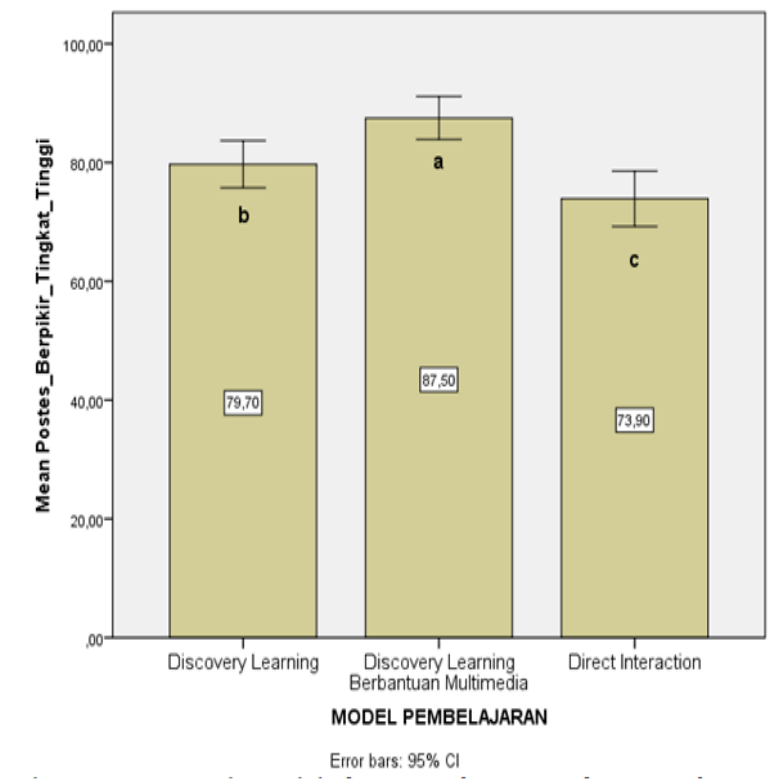

Gambar 2. Pengaruh model discovery learning, discovery learning berbantuan multimedia dan direct interaction terhadap keterampilan berpikir tingkat tinggi $(F=11,485 ; P=0,000)$. Huruf yang berbeda di atas diagram berarti berbeda signifikan (Uji Tukey).

\section{c. Pengaruh Model Discovery Learning Berbantuan Multimedia Terhadap Keterampilan Bertanya \\ Hasil pengaruh model pembelajaran} discovery learning berbantuan multimedia terhadap keterampilan bertanya dapat dilihat pada tabel 13 dibawah ini. Dari tabel di bawah berdasarkan hasil pengamatan menunjukan perbedaan pada masingmasing model pembelajaran pada kelompok 
Rahmat Surya, Pengaruh Model Discovery Learning Berbantuan Multimedia Terhadap Keterampilan Proses Sains Berpikir Tingkat Tinggi dan Keterampilan Bertanya

JURNAL BIOLOKUS Vol.3 (1)

(discovery learning) tedapat 43 pertanyaan yang masing-masing. diajukan peserta berdasarkan aspek kognitif

Tabel 13. Pengaruh Model Pembelajaran Discovery Learning Berbantuan Multimedia Terhadap Keterampilan Bertanya.

\begin{tabular}{|c|c|c|c|c|c|c|c|c|c|}
\hline \multirow{2}{*}{ No } & \multirow{2}{*}{ Kelompok } & \multirow{2}{*}{$\begin{array}{c}\text { Jumlah } \\
\text { Siswa }\end{array}$} & \multicolumn{6}{|c|}{ Aspek Kognitif } & \multirow{2}{*}{ Jumlah } \\
\hline & & & C1 & $\mathrm{C2}$ & C3 & C4 & $\mathbf{C 5}$ & C6 & \\
\hline 1 & Discovery Learning & $\mathrm{N}=31$ & 16 & 6 & 9 & 9 & 3 & 0 & 43 \\
\hline 2 & Discovery Learning berbantuan Multimedia & $\mathrm{N}=32$ & 21 & 7 & 8 & 16 & 7 & 3 & 62 \\
\hline 3 & Direct Interaction & $\mathrm{N}=34$ & 13 & 6 & 3 & 5 & 1 & 0 & 28 \\
\hline
\end{tabular}

Pada kelompok (discovery learning berbantuan multimedia) terdapat 63 pertanyaan yang diajukan peserta berdasarkan aspek kognitif masing-masing. Pada kelompok (direct interaction) terdapat 28 pertanyaan yang diajukan peserta berdasarkan aspek kognitif masing-masing. Dari uraian diatas menunjukan model discovery learning berbantuan multimedia yang menjadi unggulan pembelajaran untuk memperoleh suatu pertanyaan dikarenakan banyaknya peserta yang melakukan pertanyaan. Hal ini sejalan dengan hasil keterampilan proses sains dan berpikir tingkat tinggi di mana kelas yang di ajarkan dengan menggunakan model discovery learning berbantuan multimedia hasilnya lebih tinggi di bandingkan kelas lain yang menggunakan mode discovery learning dan direct interaction.

\section{PEMBAHASAN}

\section{Pengaruh Model Discovery Learning Berbantuan Multimedia Terhadap Keterampilan Proses Sains}

Karakteristik dari pembelajaran discovery adalah sebuah model yang menempatkan guru sebagai fasilitator. Guru membimbing siswa dimana ia diperlukan. Dalam model ini, siswa didorong untuk berpikir sendiri, menganalisis sendiri sehingga dapat "menemukan" prinsip umum berdasarkan bahan atau data yang telah disediakan.

Hasil penelitian ini memperlihatkan bahwa keterampilan proses sains yang dibelajarkan dengan model discovery learning berbantuan multimedia lebih tinggi dibandingkan hasil belajar siswa yang dibelajarkan dengan model discovery learning dan direct interaction. Kenyataan ini membuktikan bahwa model discovery learning berbantuan multimedia lebih baik dalam meningkatkan keterampilan proses sains dibandingkan dengan model pembelajaran direct interection. Model discovery learning dan discovery learning berbantu multimedia mengajak siswa berperan aktif dalam proses pembelajaran, kedua model pembelajaran ini baik secara pribadi atau kelompok dapat menemukan sendiri konsep-konsep pembelajaran melalui pemecahan masalah yang umum terjadi yang diajukan oleh guru pada saat pembelajaran.

Dari hal tersebut dapat terlihat bahwa peningkatan keterampilan proses sains dengan penerapan model discovery learning berbantuan multimedia yang diperoleh dari penelitian ini juga sejalan dengan hasil penelitian Ismu (2012) yang telah menggunakan model discovery learning berbantuan media ICT terhadap keterampilan proses sains terbukti bahwa penerapan media gambar dapat meningkatkan KPS siswa. Peningkatan KPS siswa disebabkan adanya peningkatan aktivitas siswa dalam proses pembelajaran, dari data dapat dilihat bahwa rata-rata aktivitas siswa tergolong tinggi. karena dalam pembelajaran menggunakan model discovery berbantuan simulasi komputer, siswa berperan aktif dalam proses pembelajaran dan secara kreatif berusaha menemukan permasalahan yang diajukan, saling berinteraksi dengan teman maupun guru, saling bertukar pikiran, sehingga wawasan dan daya pikir mereka berkembang dan menyadari banyak hal atau kejadian yang dapat mereka jumpai dalam kehidupan sehari-hari yang berkaitan dengan konsep fisika yang mereka pelajari.

Adanya peningkatan aktivitas belajar siswa akan meningkatkan hasil keterampilan proses sains dan hasil belajar siswa. Aktivitas belajar siswa dapat meningkat karena selama proses pembelajaran siswa dituntut untuk aktif bertanya, menjawab pertanyaan dan mengemukakan pendapat/ide.

Begitu Pula dengan penerapan model discovery learning juga mengalami peningkatan rata-rata keterampilan proses sains siswa. Dalam pembelajaran dengan model discovery learning 
Rahmat Surya, Pengaruh Model Discovery Learning Berbantuan Multimedia Terhadap Keterampilan Proses Sains Berpikir Tingkat Tinggi dan Keterampilan Bertanya

\section{JURNAL BIOLOKUS Vol.3 (1)}

siswa belajar juga dalam kelompok, tetapi tidak menggunakan multimedia sebagai media ajar dalam proses pembelajaran, hal ini senada dengan hasil penelitian Ayadiya (2014) Penerapan model pembelajaran discovery learning dengan scientific approach Untuk meningkatkan keterampilan Proses sains siswa SMA, menunjukan hasil model pembelajaran discovery learning dengan scientific approach dapat meningkatkan keterampilan proses sains siswa dengan peningkatan signifikan sebesar 13,28\%. Peningkatan tersebut terjadi karena model pembelajaran discovery learning berlandaskan pada teori- teori belajar konstruktivis. Menurut pandangan kostruktivisme, belajar adalah proses aktif siswa dalam mengonstruksi arti, wacana, dialog, dan pengalaman fisik dimana di dalamnya terjadi proses asimilasi dan menghubungkan pengalaman atau informasi yang sudah dipelajari, pembelajaran menyebabkan pengetahuan yang diperoleh siswa lebih bermakna karena pengetahuan tersebut diperoleh melalui kegiatan proses mengamati, menanya, mencoba atau mengumpulkan data dan atau informasi, mengasosiasi, dan mengkomunikasikan.

Walaupun siswa juga aktif dalam pembelajaran model discovery learning, namun pengetahuan yang melekat pada siswa tidak sebaik pembelajaran yang menggunakan model discovery learning berbantuan multimedia, hal ini dikarenakan multimedia dapat menjadikan siswa lebih aktif, dimana multimedia yang interaktif mampu memberikan nilai tambah bagi siswa dalam mengeksplorasi materi yang ada didalamnya. Menurut Gardner dalam Khairani, M. dkk (2019) salah satu teknologi multimedia video yang telah sering dieksploitasi untuk meningkatkan pengajaran dan pembelajaran adalah video pembelajaran. Video adalah alat untuk melibatkan kecerdasan verbal (linguistik), visual (spasial), dan musik (ritmis) siswa dalam proses pembelajaran, terutama dalam proses belajar mandiri. Hal ini juga didukung Lubis, J. A., dan Harahap, R. (2018) bahwa ada peningkatan pemahaman konsep pembelajaran biologi siswa melalui model pendekatan keterampilan proses pada ekosistem di kelas X SMA Negeri 3 Padangsidimpuan.

Meskipun dalam penelitian ini diperoleh data keterampilan proses sains siswa lebih tinggi jika dibelajarkan dengan model discovery learning berbantuan multimedia dibandingkan kelas yang dibelajarkan dengan discovery learning, namun pada pelaksanaannya kedua model ini secara umum telah mampu meningkatkan ratarata keterampilan proses sains pembelajaran biologi pada materi sistem pernapasan.

\section{Pengaruh Model Discovery Learning Berbantuan Multimedia Terhadap Berpikir Tingkat Tinggi}

Hasil uji lanjut menunjukan bahwa kemampuan berpikir tingkat tinggi siswa yang dibelajarkan dengan model discovery learning berbantuan multimedia berbeda signifikan dengan kelas yang dibelajarkan dengan model discovery learning dan direct interaction.

Kemampuan berpikir tingkat tinggi siswa khususnya pada materi sistem pernapasan pada manusia, dari hasil penelitian ini dapat diketahui bahwa model discovery learning berbantuan multimedia menghasilkan kemampuan berpikir tingkat tinggi yang lebih baik dibandingkan model discovery learning dan direct interaction. Materi sistem pernapasan pada manusia adalah salah satu materi dari mata pelajaran biologi, dimana materi ini erat kaitannya dengan kehidupan sehari-hari. Materi ini sesuai dengan model discovery learning yaitu suatu proses pembelajaran penemuan, siswa didorong untuk terutama belajar sendiri atau kelompok melalui keterlibatan aktif dengan konsep-konsep dan prinsip- prinsip. Guru mendorong siswa agar mempunyai pengalaman dan melakukan eksperimen dengan memungkinkan mereka menemukan prinsip-prinsip atau konsep- konsep bagi diri mereka sendiri dan ditambah lagi berbantuan dengan multimedia, dimana multimedia menjadi siswa lebih aktif, interaktif dan mampu memberikan nilai tambah bagi siswa dalam mengeksplorasi materi yang ada didalamnya.

Dari hal tersebut dapat terlihat bahwa siswa yang dibelajarkan dengan model discovery learning berbantuan multimedia dapat mengembangkan kemampuan intelek mereka, siswa tidak hanya dituntut untuk menguasai materi pembelajaran, akan tetapi bagaimana mereka peroleh dapat dipahami dengan baik sehingga mereka dapat meningkatkan keterampilan proses sains.

Hasil penelitian ini sesuai dengan Sumarni (2013) pembelajaran berbasis multimedia untuk meningkatkan penguasaan konsep kimia dan keterampilan berpikir mahasiswa dengan hasil 
Rahmat Surya, Pengaruh Model Discovery Learning Berbantuan Multimedia Terhadap Keterampilan Proses Sains Berpikir Tingkat Tinggi dan Keterampilan Bertanya

\section{JURNAL BIOLOKUS Vol.3 (1)}

penelit ian pembelajaran berbasis multimedia mampu meningkatkan penguasaan kemampuan berpikir tingkat tinggi untuk kelompok eksperimen pada tingkat capaian tinggi, sedangkan pada kelompok kontrol hanya pada tingkat capaian sedang. Meskipun dalam penelitian ini diperoleh data berpikir tingkat tinggi siswa lebih tinggi jika dibelajarkan dengan model discovery learning berbantuan multimedia dibandingkan kelas yang dibelajarkan dengan discovery learning dan direct interaction, namun pada pelaksanaannya kedua model ini secara umum telah mampu meningkatkan rata-rata berpikir tingkat tinggi siswa dalam pembelajaran biologi pada materi sistem pernapasan.

\section{Pengaruh Model Discovery Learning Berbantuan Multimedia Terhadap Keterampilan Bertanya}

Jika ditinjau berdasarkan hasil penelitian pengaruh model discovery learning berbantuan multimedia terhadap keterampilan bertanya siswa pada model discovery learning, discovery learning berbantuan multimedia dan direct interaction hasil perhitungan keterampilan bertanya siswa dengan model discovery learning berbantuan multimedia lebih tinggi dibandingkan dengan keterampilan bertanya siswa dengan yang diajarkan dengan model discovery learning dan direct interaction, dan keterampilan bertanya model discovery learning lebih tinggi dibandingkan dengan siswa yang diajarkan dengan model direct interaction. Dalam model discovery learning berbantuan multimedia siswa didorong untuk terutama belajar sendiri melalui keterlibatan aktif dengan konsepkonsep dan prinsip-prinsip.

Hasil penelitian ini sesuai dengan Wijayanti (2013) Peningkatan keterampilan bertanya (Posing Question) melalui Penerapan discovery learning berbasis multimedia pada materi ekosistem dimana terjadinya peningkatan keterampilan bertanya (Posing Question) melalui penerapan discovery learning berbasis multimedia.

\section{SIMPULAN}

Berdasarkan hasil penelitian dan pembahasan yang telah diuraikan maka dapat disimpulkan bahwa; (1) Ada pengaruh model discovery learning berbantuan multimedia terhadap keterampilan proses sains di SMA Negeri 5 Langsa. Keterampilan proses sains di kelas yang menggunakan discovery learning berbantuan multimedia $(92,057 \pm 5,585)$, discovery learning $(81,458 \pm 11,647)$, dan direct interaction $(73,417 \pm 13,682)$ dengan nilai $\mathrm{F}=24,080, p=0,000$, (2) Ada pengaruh model discovery learning berbantuan multimedia terhadap berpikir tingkat tinggi siswa pada materi sistem pernapasan di kelas XI SMA Negeri 5 Langsa. Berpikir tingkat tinggi siswa yang menggunakan discovery learning berbantuan multimedia $(87,499 \pm 10,03)$, discovery learning $(79,703 \pm 10,79)$, dan direct interaction $(73,897 \pm 13,38)$ terhadap berpikir tingkat tinggi dengan nilai $\mathrm{F}=11,485$, $p=0,000$, (3) Ada pengaruh model discovery learning berbantuan multimedia terhadap keterampilan bertanya peserta didik, pada model discovery learning berbantuan multimedia lebih banyak yang bertanya dibandingkan dengan model pembelajaran discovery learning dan direct interaction pada materi sistem pernapasan di kelas XI SMA Negeri 5 Langsa.

\section{REFERENSI}

Arends, R. I. (2001). Exploring Teaching: An Introduction to Education. New York: McGrawHill.

Arends, R. I. (2012). Learning to Teach Ninth Edition. New York: McGraw- Hill.

Arikunto, S. (2003). Dasar-dasar Evaluasi Pendidikan. Jakarta: Bumi Aksara.

Arikunto, S. (2006). Prosedur Penelitian Suatu Pendekatan Praktik. Jakarta: Rineka Cipta.

Dahar, R. W. (2011). Teori-teori Belajar dan Pembelajaran. Jakarta: Erlangga.

Depdiknas. (2003). Pendidikan Kontekstual Teaching and Learning. Jakarta: Depdiknas.

Depdiknas. (2006). Berbagai Pendekatan dan Model dalam Pembelajaran. Jakarta: Ditjen Dikdasmen, Direktorat Pendidikan Lanjutan Pertama.

Dimyanti. (2006). Belajar dan Pembelajaran. Jakarta: Rineka Cipta.

Dimyati \& Mudjiono. (2010). Belajar dan Pembelajaran. Jakarta: Rineka Cipta.

Djamarah. (2002). Strategi Belajar Mengajar. Jakarta: Rineka Cipta. 
Rahmat Surya, Pengaruh Model Discovery Learning Berbantuan Multimedia Terhadap Keterampilan Proses Sains Berpikir Tingkat Tinggi dan Keterampilan Bertanya

JURNAL BIOLOKUS Vol.3 (1)

Dwyer, Francis, \& Lin, H. (2010). The Effect of Static and Animated Visualization: A Perspective of Instructional Effectiveness and Efficiency. Pennsylvania: The Pennsylvania State University.

Dwyer, Tim. (2010). Media Convergence: Issues in Cultural and Media Studies. McGraw Hill \& Open University Press. London.

Dyers, J.H., et al. (2011). Innovators DNA: Mastering the Five Skilss of Disruptive Innovators. Harvard Business Review.

Febriani, H. (2013). Pengaruh Metode Discovery Learning dalam tatanan pembelajaran Kooperatif Tipe Jigsaw terhadap hasil belajar biologi dan kecakapan sosial siswa SMP Swasta PGRI 2 Medan. Jurnal Pendidikan Biologi, 2(3), 116-124

Fisher, A. (2009). Berpikir Kritis: Sebuah Pengantar (Ed Benyamin Hadinata), Jakarta: Erlangga.

Freeman, J. \& Utami M. (2001), Cerdas dan Cemerlang. Jakarta: Gramedia.

Gronlund, Norman E, (1973), Preparing CriterionReferenced Test for Classroom Instruction. New York: The Macmillan Publishing Company.

Hamalik, O. (2001). Proses Belajar Mengajar. Jakarta: Bumi Aksara.

Heong, Y. M., Othman, W.D., Md Yunos, J., Kiong, T.T., Hassan, R., \& Mohamad, M.M. (2011). The Level of Marzano Higher Order Thinking Skills Among Technical Education Students. International Journal of Social and Humanity, 1(2), 121-125.

Ismu, R, Pramudiyanti, Yolida, B. (2012). Pengaruh Penggunaan Media ICT Melalui Metode Discovery Terhadap Keterampilan Proses Sains,14 (2), 102-112.

Joice, B. \& Weil, M. (1972). Conceptual Complexity Teaching Style and Models of Teaching. Columbia University.

Kawuwung, F. (2011). Profil Guru, Pemahaman Kooperatif NHT, dan Kemampuan Berpikir Tingkat Tinggi di SMP Kabupaten Minahasa Utara, Jurnal El-hayah, 1(4), 157-166.

Khairani, M., Sutisna., \& Suyanto, S. (2019). Studi Meta-Analisis Pengaruh Video Pembelajaran Terhadap Hasil Belajar Peserta Didik. Jurnal Biolokus, Vol.2 (1) 158 - 166
DOI

http://dx.doi.org/10.30821/biolokus.v2i1.442

King, F. J., Goodson, L., \& Rohani, F. (2006). Higher Order Thinking Skills: Definition, Teaching Strategies, and Assesment. London: A publication of the Educational Services Program.

Krathwohl, D. R. (2002). A revision of Bloom's Taxonomy: an overview- Theory Into Practice, College of Education. The Ohio State University Pohl.

Lubis, Jalilah. A., dan Harahap, Risnawati. (2018). Penerapan Pendekatan Keterampilan proses Untuk Meningkatkan Pemahaman Konsep Pembelajaran Biologi Siswa di SMA Negeri 3 Padangsidimpuan. Jurnal Biolokus, Vol.1 (2) 101-108 DOI

http://dx.doi.org/10.30821/biolokus.v1i2.350

Sani, R. A. (2013). Inovasi Pembelajaran. Jakarta: Bumi Aksara. 